\title{
Hard time to be parents? Sea urchin fishery shifts potential reproductive contribution of population onto the shoulders of the young adults.
}

Barbara Loi ${ }^{\text {Corresp., }}{ }^{1,2}$ ， Ivan Guala ${ }^{1}$, Rodrigo Pires da Silva ${ }^{1}$, Gianni Brundu ${ }^{1,2}$, Maura Baroli ${ }^{1}$, Simone Farina

1 IMC - International Marine Centre, Torregrande, Oristano, 09170, Italy

2 Department of Ecological and Biological Sciences, University of Tuscia, Viterbo, Italy

Corresponding Author: Barbara Loi

Email address: b.lo@@fondazioneimc.it

Background. In Sardinia, as in other regions of the Mediterranean Sea, sustainable fisheries of the sea urchin Paracentrotus lividus have become a necessity. At harvesting sites, the systematic removal of large individuals (diameter $\geq 50 \mathrm{~mm}$ ) seriously compromises the biological and ecological functions of sea urchin populations. Specifically, in this study, we compared the reproductive potential of the populations from Mediterranean coastal areas which have different levels of sea urchin fishing pressure. The areas were located at Su Pallosu Bay, where pressure is high and Tavolara-Punta Coda Cavallo, a marine protected area where sea urchin harvesting is low. Methods. Reproductive potential was estimated by calculating the gonadosomatic index (GSI) from June 2013 to May 2014 both for individuals of commercial size (diameter without spines, $\mathrm{TD} \geq 50 \mathrm{~mm}$ ) and the undersized ones with gonads ( $30 \leq \mathrm{TD}<40 \mathrm{~mm}$ and $40 \leq \mathrm{TD}<50$ $\mathrm{mm})$. Gamete output was calculated for the commercial-size class and the undersized individuals with fertile gonads $(40 \leq T D<50 \mathrm{~mm}$ ) in relation to their natural density (gamete output per $\mathrm{m}^{2}$ ). Results. The reproductive potential of populations was slightly different at the beginning of the sampling period but it progressed at different rates with an early spring spawning event in the high-pressure zone and two gamete depositions in early and late spring in the low-pressure zone. For each fertile size class, GSI values changed significantly during the year of our study and between the two zones. Although the multiple spawning events determined a two-fold higher total gamete output of population (popTGO) in the low-pressure zone, the population mean gamete output (popMGO) was similar in the two zones. In the high-pressure zone, the commercial-sized individuals represented approximatively $5 \%$ of the population, with almost all the individuals smaller than $60 \mathrm{~mm}$ producing an amount of gametes nearly three times lower than the undersized ones. Conversely, the high density of the undersized individuals 
released a similar amount of gametes to the commercial-size class in the low-pressure zone. Discussion. Overall, the lack of the commercial-size class in the high-pressure zone does not seem to be very alarming for the self-supporting capacity of the population, and the reproductive potential contribution seems to depend more on the total density of fertile sea urchins than on their size. However, since population survival in the highpressure zone is supported by the high density of undersized sea urchins between 30 and $50 \mathrm{~mm}$, management measures should be addressed to maintain these sizes and to shed light on the source of the larval supply. 


\section{Hard time to be parents? Sea urchin fishery shifts potential}

\section{2 reproductive contribution of population onto the shoulders of the}

\section{3 young adults.}

4

5 Barbara Loi ${ }^{1,2}$, Ivan Guala ${ }^{1}$, Rodrigo Pires da Silva ${ }^{1}$, Gianni Brundu ${ }^{1,2}$, Maura Baroli ${ }^{1}$, Simone

6 Farina $^{1}$

$7 \quad{ }^{1}$ IMC - International Marine Centre, Torregrande, Oristano, Italy

$8{ }^{2}$ Department of Ecological and Biological Sciences (DEB), University of Tuscia, Viale dell'Università,

9 Viterbo, Italy

10

11 Corresponding author:

12 Barbara Loi

13 IMC - International Marine Centre, Torregrande, Oristano, 09170, Italy

14 Email address: b.loi@fondazioneimc.it

15

16

17 
18 ABSTRACT

Background. In Sardinia, as in other regions of the Mediterranean Sea, sustainable fisheries of the sea urchin Paracentrotus lividus have become a necessity. At harvesting sites, the systematic removal of large individuals (diameter $\geq 50 \mathrm{~mm}$ ) seriously compromises the biological and ecological functions of sea urchin populations. Specifically, in this study, we compared the reproductive potential of the populations from Mediterranean coastal areas which have different levels of sea urchin fishing pressure. The areas were located at Su Pallosu Bay, where pressure is high and Tavolara-Punta Coda Cavallo, a marine protected area where sea urchin harvesting is low.

Methods. Reproductive potential was estimated by calculating the gonadosomatic index (GSI) from June 2013 to May 2014 both for individuals of commercial size (diameter without spines, $\mathrm{TD} \geq 50 \mathrm{~mm})$ and the undersized ones with gonads $(30 \leq \mathrm{TD}<40 \mathrm{~mm}$ and $40 \leq \mathrm{TD}<50 \mathrm{~mm}$ ). Gamete output was calculated for the commercial-size class and the undersized individuals with fertile gonads $\left(40 \leq \mathrm{TD}<50 \mathrm{~mm}\right.$ ) in relation to their natural density (gamete output per $\mathrm{m}^{2}$ ).

Results. The reproductive potential of populations was slightly different at the beginning of the sampling period but it progressed at different rates with an early spring spawning event in the high-pressure zone and two gamete depositions in early and late spring in the low-pressure zone. For each fertile size class, GSI values changed significantly during the year of our study and between the two zones. Although the multiple spawning events determined a two-fold higher total gamete output of population (popTGO) in the low-pressure zone, the population mean gamete output (popMGO) was similar in the two zones. In the high-pressure zone, the commercial-sized individuals represented approximatively $5 \%$ of the population, with almost all 
40 the individuals smaller than $60 \mathrm{~mm}$ producing an amount of gametes nearly three times lower

41 than the undersized ones. Conversely, the high density of the undersized individuals released a

42 similar amount of gametes to the commercial-size class in the low-pressure zone.

43 Discussion. Overall, the lack of the commercial-size class in the high-pressure zone does not

44 seem to be very alarming for the self-supporting capacity of the population, and the reproductive

45 potential contribution seems to depend more on the total density of fertile sea urchins than on

46 their size. However, since population survival in the high-pressure zone is supported by the high

47 density of undersized sea urchins between 30 and $50 \mathrm{~mm}$, management measures should be

48 addressed to maintain these sizes and to shed light on the source of the larval supply.

\section{INTRODUCTION}

51 Commercial fisheries are one of the main causes of the deterioration of marine communities

52 (Jackson et al., 2001). The systematic removal of fishery resources drastically reduces natural

53 stocks and changes growth, production and recruitment of target species (Pinnegar et al., 2000).

54 In extreme cases, overfished populations are still present in the community but no longer interact

55 significantly with other species (Estes, Duggins \& Rathbun, 1989). This phenomenon can lead to

56 a simplification of trophic webs with dramatic consequences for marine ecosystems (Pauly,

57 1995; Myers \& Worm, 2003; Coll, Lotze \& Romanuk, 2008a; Coll, Palomera \& Tudela, 2009a;

58 Coll et al., 2009b; Lotze, Coll \& Dunne, 2011; Navia et al., 2012; Tunca et al., 2016).

59 One of the clearest examples reported for several temperate coastal systems is the

60 overexploitation of target species involved in the typical tri-trophic interaction "fish-sea urchins- 
61 macrophyte". Trophic relationships can be altered by overfishing predatory fishes. This triggers

62 an uncontrolled proliferation of sea urchins which then leads to an overgrazing of algal cover

63 (Sala, Boudouresque \& Harmelin-Vivien, 1998; Steneck et al., 2002; Steneck, Vavrinec \&

64 Leland, 2004). Although this is the main effect of overfishing on many Mediterranean coasts

65 (Sala \& Zabala, 1996; Sala, Boudouresque \& Harmelin-Vivien, 1998), trophic imbalances have

66 also been found to act in the opposite direction. Indeed, over the last 2-3 decades, the general

67 decline of natural fish stocks has led to a focus on new target species, often further down the

68 food web.

69

In many regions sea urchin harvesting was added to higher-trophic-level fisheries (Anderson et al., 2011). This is the case of some regions in the South of Italy where the edible sea urchin Paracentrotus lividus (Lamarck, 1816) is subjected to high fishing pressure (Tortonese, 1965; Guidetti, Terlizzi \& Boero, 2004; Pais et al., 2007). The most striking effect of sea urchin fishing is the rapid decrease in commercial resources in terms of total density and abundance (Andrew et al., 2002; Bertocci et al., 2014). A remarkable reduction in density and mean size of the sea urchin population would have dramatic consequences for the whole benthic community. For instance, the removal of hundreds of thousands of sea urchins from the temperate reef has coincided with the rapid development of brown algae that has led to substantial changes in the abundance of fish and benthic invertebrates (Bell et al., 2014).

Furthermore, the decline of sea urchin populations due to harvesting by humans could be even more significant because of the loss of sexually mature individuals that contribute to the local recruitment pool (Levitan \& Sewell, 1998). Indeed, gonads are proportional to a sea urchin's body-size and are more mature and developed in large sea urchins (Mita et al., 2007). 
83 The gonadosomatic index (GSI) is generally used to evaluate the reproductive features of

84 echinoids such as fluctuations in gonad size and spawning periods (Spirlet, Grosjean \& Jangoux, 1998; Shpigel et al., 2004; Gianguzza et al., 2013) and these relate to the reproductive potential of the individual (Brewin et al., 2000). Fertile size classes can produce more than one cohort of mature gametes in a single breeding season (Mita et al., 2007) and the reproductive cycle generally has one or two seasonal GSI peaks (see reviews in Boudouresque \& Verlaque, 2007 and Ouréns, Fernandez \& Freire, 2011). Sometimes there can be continuous spawning events of lower significance and with strong dependence on the variability of the gametogenesis (Boudouresque \& Verlaque, 2007). Generally, GSI shows considerable spatial and temporal variability as a result of extrinsic factors such seasonal changes in photoperiod, water temperature and phytoplankton blooms (see Ouréns, Fernandez \& Freire, 2011 and references therein). Food quality and availability (Byrne, 1990; Minor \& Scheibling, 1997; Brady \& Scheibling, 2006; Scheibling \& Hatcher, 2007) as well as hydrodynamic conditions (Lozano et al., 1995; Meidel \& Scheibling, 1998; Guettaf, San Martin \& Francour, 2000; Sellem \& Guillou, 2007; Gianguzza et al., 2013) can also influence the reproductive cycle and fecundity of populations.

In Sardinia (Italy, Western Mediterranean), commercial fishing of the sea urchin Paracentrotus lividus is limited by law to specimens larger than $50 \mathrm{~mm}$ test diameter (TD), from November to April. However, despite regional decrees concerning fishing periods, minimum size and catch quotas per day per fisherman, the harvesting of $P$. lividus is intensively practiced. Removal by occasional recreational fishermen occurs throughout the year because of the long tourist season (Pais et al., 2007). The systematic removal of the largest sea urchins may decrease the number of 
105 fertile individuals that release gametes into the surrounding environment. This leads to a

106 population collapse, as reported for some overfished areas (Pais et al., 2007).

107 The aim of this work is to assess the reproductive potential of populations living in two zones of

108 Sardinia which have different harvesting pressure and to compare, through the evaluation of the

109 GSI over one year, the annual gamete output (Brewin et al., 2000) of the commercial-size class

110 (diameter without spines, $\mathrm{TD} \geq 50 \mathrm{~mm})$ and the fertile, undersized one $(40 \leq \mathrm{TD}<50 \mathrm{~mm})$ of

111 both populations. Our hypothesis supports that, under high fishing pressure, the contribution of

112 the commercial-size class to reproductive potential drastically decreases and, as a result, the risk 113 of a population collapse increases.

115 MATERIALS AND METHODS

116 Study sites and sea urchin sampling

117 The reproductive potential of the Paracentrotus lividus populations was examined in two zones

118 of Sardinia that differ in sea urchin fishing pressure (Fig. 1). These two zones were selected

119 because they are at two extremes as regards the exploitation of sea urchins in Sardinia. Su

120 Pallosu Bay, located along the Sinis peninsula (central-western Sardinia, $40^{\circ} 03^{\prime} \mathrm{N} ; 008^{\circ} 25^{\prime} \mathrm{E}$ ),

121 is subjected to very high pressure (HP zone) which is widespread across the entire bay.

122 Harvesting can be practised through scuba diving from November to April by 189 professional

123 fishermen authorized by regional decree. Each one of them, when helped by an assistant, is

124 allowed to collect up to 3000 sea urchins ( $\mathrm{TD} \geq 50 \mathrm{~mm}$ ) per day, according to the regional

125 decree n. 1967/DecA/67 issued by the Regione Autonoma Sardegna (RAS, 2013). 
126 On the contrary, the marine protected area of Tavolara - Punta Coda Cavallo (north-eastern

127 Sardinia, $40^{\circ} 53^{\prime} \mathrm{N}$; $009^{\circ} 40^{\prime} \mathrm{E}$ ) is considered a low-pressure zone (LP zone). This marine

128 reserve was legally established in 1997 and has been considered well-enforced since 2003 (Di

129 Franco et al., 2009). This is one of the few zones in Sardinia where sea urchin fishing is strongly

130 restricted (there are only few authorized fishermen and no more than 500 catches per day for an

131 overall maximum of 300,000 sea urchins harvested each year) and the populations are well

132 preserved (Guala et al., 2011). Although no data are available on annual catches, Su Pallosu Bay

133 is among the most exploited in the whole region and the theoretical number of sea urchins that

134 can be legally harvested in one year (calculated according to the number of licenses, allowed

135 catches and fishing days) is over 300 times greater than that of Tavolara - Punta Coda Cavallo.

136 Sea urchin specimens were collected from two areas of high harvesting pressure (A and B) at $\mathrm{Su}$

137 Pallosu Bay, and low harvesting pressure (C and D) at Tavolara MPA. In each zone, the two

138 areas were 1-3 km apart. Sampling (approved by the Regione Autonoma Sardegna through the

139 release of the fishing license for scientific purposes n. 9727/AP SCIE/N.7 03/06/2016) involved

140 all sea urchin size classes that have gonads and contribute to the reproductive potential of the

141 population. Specifically, once a month, we collected 10 individuals of the commercial size (CS,

$142 \mathrm{TD} \geq 50 \mathrm{~mm}$ ), 5 undersized individuals (US, $40 \leq \mathrm{TD}<50 \mathrm{~mm}$ ) and 5 smaller, undersized sea

143 urchins (Small-US, $30 \leq \mathrm{TD}<40 \mathrm{~mm}$ ) for an entire year.

144 The sea urchins were collected from both zones by scuba diving over a rocky bottom covered in

145 photophilic algal communities at a depth of five meters. Sea urchin samples were wrapped in

146 cloth soaked in salt water, stocked in iceboxes and immediately transported to the laboratory. 
149 Despite the differences in position along the Sardinian coast and in wind exposure, sampling was

150 performed in areas with similar environmental features (i.e. depth, slope, shelter from the

151 waves), on rocky bottoms.

152 Differences in food availability, potentially able to affect sea urchin gonad growth and 153 consequently fecundity (Byrne, 1990; Minor \& Scheibling, 1997; Brady \& Scheibling, 2006;

154 Scheibling \& Hatcher, 2007), were assessed as temporal changes of algal cover between zones.

155 Digital photographs were taken over three PVC quadrats of 50 x $50 \mathrm{~cm}$ which were randomly

156 placed on the sea bottom in each area. This was done three times (July 2013, January and May

157 2014) during the surveyed year. Image analysis was carried out using Seascape ${ }^{\circledR}$ software

158 (Segmentation and Cover Classification Analyses of Seabed Images, Teixidó et al., 2011) to

159 detect the percentage cover of conspicuous algal taxa or morphological groups. A permutational

160 multivariate analysis of variance (PERMANOVA, Anderson, 2001a) was done, on the basis of a

161 Bray-Curtis dissimilarity matrix calculated from square-root transformed data (Primer-E 6

162 Permanova $\left.{ }^{\circledR}\right)$, to estimate the variability of assemblages between the two zones over time. A 3-

163 way model was used with Time (random, 3 levels) and Zone (fixed, 2 levels, Su Pallosu Bay vs.

164 Tavolara - Punta Coda Cavallo) as crossed factors, and Area (2 levels) as a random factor nested

165 in Zone. P-values were obtained through Monte Carlo random draws from the asymptotic

166 permutation distribution (Anderson, 2005) and a pairwise test was used to discriminate between

167 various levels of significant factors. A non-metric Multi-Dimensional Scaling (nMDS)

168 ordination was used as a graphical representation of data.

169 In order to investigate any potential thermic anomalies, seasonal variations of the coastal water

170 temperature were monitored with the "Mediterranean Sea - High Resolution and Ultra High

171 Resolution L3S Sea Surface Temperature" product (http://marine.copernicus.eu/web/69- 
172 myocean-interactive-catalogue.php). Daily sea surface temperatures (SST) were extrapolated

173 from the catalogue after choosing an intermediate point between the two sampling areas within

174 the zones, then mean monthly temperatures were obtained and used to represent the annual trend.

\section{Gonadosomatic Index and fertility}

177 The gonadosomatic index (GSI) was examined every month from June 2013 to May 2014 (with

178 the exception of November due to adverse weather conditions) for all of the three sampled size

179 classes. Sea urchins were allowed to drip dry for some minutes and then weighed. The test

180 diameter (TD) without spines was measured and the gonads were successively extracted and

181 weighed as well.

182 GSI was calculated by the formula: GSI = [gonad wet weight / total wet weight $] \times 100$ as

183 reported by Lawrence, Lawrence \& Holland (1965).

184 The fertility was tested according Brundu et al. (2016) during the months of maximum gonadal

185 development (i.e. from December to April). Gonads from females were extracted and gently

186 shaken in filtered seawater to allow the mature ova to come out. Sperm was then added and

187 finally, the fertility of the individuals was assessed as a percentage of the effectively fertilized

188 eggs after the appearance of the fertilization membrane (fertilization was considered successful if

189 it took place in at least $80 \%$ of the eggs according Falugi \& Angelini, 2002). The percentage of

190 achievement of the first larval stage (development of four-arm echinopluteus) was also

191 measured. The fertility test was carried out on the US individuals but not on Small-US specimens

192 because of the paucity of their gonads (see "Results"). Nor was it done on the commercial-sized

193 individuals (CS) because they were assumed to be fertile (Ouréns, Fernández \& Freire, 2011). 
194 Monthly mean values of GSI were calculated for the two zones and areas of sampling. Since sex 195 ratio was nearly 1:1 for both sampling zones (Data S8), females and males were pooled together 196 to obtain a single mean GSI value per month. A four-way ANOVA (using Statistica 6.0, Statsoft 197 Inc.) was performed to highlight the differences in GSI values in different months (fixed and 198 orthogonal factor, 11 levels), zones (fixed and orthogonal factor, 2 levels), areas (random and 199 nested in zones, 2 levels), and fertile size classes (fixed and orthogonal factor, 2 levels, CS and 200 US). Eight replicates for each size class were haphazardly selected from among those available 201 in order to get a balanced design. Cochran's C test was used to check for the assumption of 202 homogeneity of variances and a posteriori SNK tests were performed to find alternative 203 hypotheses (Underwood, 1997).

\section{Population structure and potential reproductive contribution}

Abundance and size-frequency distribution of the populations were estimated for both zones by counting all sea urchins found in the PVC plots and measuring them with calipers. The plots were $50 \times 50 \mathrm{~cm}$ and were placed randomly as many times as necessary to cover two replicates of $25 \mathrm{~m}^{2}$ in each area $\left(100 \mathrm{~m}^{2}\right.$ for each zone $)$.

Sea urchin abundance was estimated as the total density (individuals $\mathrm{m}^{-2}$ ) and the density of each $10 \mathrm{~mm}$ size class: $\mathrm{TD}<10 \mathrm{~mm}, 10 \leq \mathrm{TD}<20 \mathrm{~mm}, 20 \leq \mathrm{TD}<30 \mathrm{~mm}, 30 \leq \mathrm{TD}<40 \mathrm{~mm}, 40 \leq$

$212 \mathrm{TD}<50 \mathrm{~mm}$ and $50 \leq \mathrm{TD}<60 \mathrm{~mm}, \mathrm{TD} \geq 60 \mathrm{~mm}$. Size-class densities were then translated into

213 frequency percentages and used to compose the population structure for each zone. The gamete 214 output and the spawning magnitude of each spawning event were calculated for the fertile CS and US classes according to Brewin et al. (2000). The highest and the lowest mean monthly GSI

216 recorded during the year of sampling corresponded to the period just before the beginning (pre- 
217 spawning) and after the end (post-spawning) of the spawning events. We defined the mean

218 individual gamete output (IGO), in units of gamete wet weight per urchin per spawning event (g

$219 \mathrm{~g}^{-1} \mathrm{se}^{-1}$ ), as the difference of the mean monthly pre-spawning GSI and the mean monthly post-

220 spawning GSI. The spawning magnitude was defined as the percentage ratio of the mean

221 individual gamete output and the mean monthly pre-spawning GSI.

222 For each spawning event, we calculated the gamete output per $\mathrm{m}^{2}\left(\mathrm{GO}, \mathrm{g} \mathrm{g}^{-1} \mathrm{~m}^{-2} \mathrm{se}^{-1}\right)$, released by

223 fertile size classes in both zones, as their IGO multiplied for the respective natural density. The

224 total gamete output (TGO) and the mean gamete output (MGO), used to estimate the reproductive

225 contribution of each size class per $\mathrm{m}^{2}$ per year, were defined respectively as the sum and the

226 average of GO $\left(\mathrm{g} \mathrm{g} \mathrm{g}^{-1} \mathrm{~m}^{-2} \mathrm{yr}^{-1}\right)$. Finally, the potential reproductive contribution of the whole

227 population in both zones (popTGO and popMGO, respectively) were calculated for the

228 investigated year as the sum of the contributions of both fertile size classes.

\section{RESULTS}

\section{Environmental features}

Multivariate analysis on algal cover has detected a significant interaction between Time and

Zone. More specifically, pairwise tests highlighted that algae where sea urchins live changed significantly over time but not between the two zones (Table S1). The nMDS showed that plots of the HP zone were interspersed on the graph with those of the LP zone (Fig. S2). trend between the two zones studied (Fig. S3). 
239 Gonadosomatic Index and fertility

240 At each area, 220 specimens of the commercial-size class (CS) and 110 undersized and smaller

241 undersized individuals (US and Small-US) were randomly collected over a year to compare

242 reproductive potential between populations. Regarding CS individuals, sampled sea urchins with

$243 \mathrm{TD} \geq 60 \mathrm{~mm}$ were 24 of $440(5.5 \%)$ in the HP zone and 219 of $417(53 \%)$ in the LP zone.

244 Fertility tests showed that $100 \%$ of the undersized individuals (US) checked were fertile and

245 contributed to the reproductive potential of the populations, with high percentages of fertilized

246 eggs (ranging from 87 to 96\%) and developing larvae (ranging from 95 to 100\%) (Table S4).

247 Conversely, the Small-US individuals had reduced gonads (Fig. 2) and, even during the period of

248 maximum development, they never released gametes, therefore their contribution to the

249 reproductive potential of the population can be considered negligible.

250 The GSI trend over the year was generally higher for CS individuals than US ones for both zones

251 (Fig. 2). At the HP zone, we recorded a single large spawning period from March to May for

252 both fertile classes (see Fig. 2a). In pre-spawning time, GSI values reached $6.6 \pm 0.3 \%(\mathrm{mean} \pm$

253 standard error) and $4.4 \pm 0.4 \%$, while in post-spawning time values were $1.3 \pm 0.2 \%$ and $1.6 \pm$

$2540.1 \%$ for the CS and US classes respectively (Fig. 2a).

255 At the LP zone, a spawning event was observed twice (Fig. 2b). The first one was recorded from

256 June to December with a pre-spawning GSI of $6.7 \pm 0.3 \%$ and $5.2 \pm 0.5 \%$, and a post-spawning

257 GSI of $2.5 \pm 0.3 \%$ and $1 \pm 0.2 \%$ for the CS and US classes respectively. The second spawning

258 event occurred from February to April with a pre-spawning GSI of $5.4 \pm 0.4 \%$ and a post-

259 spawning GSI of $2.5 \pm 0.2 \%$ for the CS class. From February to May we observed a pre-

260 spawning GSI of $4 \pm 0.6 \%$ and a post-spawning GSI of $1.2 \pm 0.2 \%$ for the US class (Fig. 2b). 
261 ANOVA highlighted significant differences during the year and between the different size

262 classes, while there were no major statistical differences found between sampling areas and

263 zones. The CS class had higher GSI values in the LP zone while no differences were found for

264 the US individuals (Table 1). A significant interaction between Zone and Size Class was

265 detected, and the GSI of the CS class was significantly higher than that of the US individuals for

266 both zones. A significant interaction was also found between Month and Size Class with SNK

267 pointing out significantly higher GSI values for the CS individuals during the whole sampling 268 year excluding April (Table 1).

269

270

\section{Population structure and potential reproductive contribution}

271 Size class distribution was consistently different between the two zones (Fig. 3). In the HP zone,

272 sea urchin density was almost two-fold higher than in the LP zone: $10 \pm 1.4$ and $5.4 \pm 0.5$

273 individuals per $\mathrm{m}^{2}$ respectively. Sea urchins with TD ranging from 0 to $20 \mathrm{~mm}$ were $1.7 \pm 0.1$ per

$274 \mathrm{~m}^{2}$ and $1.1 \pm 0.6$ per $\mathrm{m}^{2}$ in the HP and LP zones respectively, and they represent $17 \%$ and $21 \%$

275 of their populations. The most abundant size classes were those ranging from 20 to $50 \mathrm{~mm}$

276 diameter (77\%) with a density of $3 \pm 0.6$ and $3 \pm 0.3$ individuals per $\mathrm{m}^{2}$ for the Small-US and US

277 classes respectively $(30 \leq \mathrm{TD}<40 \mathrm{~mm}$ and $40 \leq \mathrm{TD}<50 \mathrm{~mm})$. The proportion of individuals of

278 the CS class with respect to the entire population was $6 \%\left(0.6 \pm 0.2\right.$ individuals per $\left.\mathrm{m}^{2}\right)$ and all

279 the individuals were included in the range of $50 \leq \mathrm{TD}<60 \mathrm{~mm}$ (Fig.3). In the LP zone, the

280 individuals between 20 and $50 \mathrm{~mm}$ represented $28 \%$ of the population while the CS class was

$28152 \%$ with $1 \pm 0.4$ and $2 \pm 0.2$ individuals per $\mathrm{m}^{2}$ for $50 \leq \mathrm{TD}<60 \mathrm{~mm}$ and $\mathrm{TD} \geq 60 \mathrm{~mm}$

282 respectively (Fig. 3). 
283 In relation to the population structure, the reproductive contribution was compared between the

284 two zones, but no comparisons were made between the sampling areas because no differences

285 were found (see Table 1). The potential reproductive contribution was calculated according to

286 the number of spawning events during the surveyed year and the natural density of the fertile size

287 classes (US and CS). In the HP zone, a single spawning event occurred and the spawning

288 magnitude for the year was $73 \%$ on average (Table 2) with an individual gamete output (IGO) of

2890.03 and $0.05 \mathrm{~g} \mathrm{~g}^{-1} \mathrm{se}^{-1}$ for the US and CS individuals, respectively (Table 2). The gamete output

290 (GO), calculated in relation to the natural density of this zone, was $0.08 \mathrm{~g} \mathrm{~g}^{-1} \mathrm{~m}^{-2} \mathrm{se}^{-1}$ for the US

291 sea urchins $\left(2.7 \pm 0.3\right.$ individuals per $\left.\mathrm{m}^{2}\right)$ and $0.03 \mathrm{~g} \mathrm{~g}^{-1} \mathrm{~m}^{-2} \mathrm{se}^{-1}$ for the CS class $(0.6 \pm 0.2$

292 individuals per $\mathrm{m}^{2}$ ). Because of the single spawning event, the total gamete output per $\mathrm{m}^{2}$ (TGO)

293 overlaps the mean gamete output per $\mathrm{m}^{2}$ (MGO) (Table 2). Accordingly, the total gamete output

294 of the whole population (i.e. sum of TGO of the two fertile size classes) corresponded to the

295 mean gamete output for $\mathrm{m}^{2}$ (popMGO) with a value of $0.11 \mathrm{~g} \mathrm{~g}^{-1} \mathrm{~m}^{-2} \mathrm{yr}^{-1}$ (Table 2).

296 Conversely, in the LP zone, two spawning events were observed (Fig. 2b). Spawning magnitude

297 varied from 54 to $81 \%$ with higher values for US individuals (Table 2). IGO was similar for both

298 size classes with values ranging from 0.03 to $0.04 \mathrm{~g} \mathrm{~g}^{-1} \mathrm{se}^{-1}$ according to the spawning period.

299 The GO of the US individuals was $0.02 \mathrm{~g} \mathrm{~g}^{-1} \mathrm{~m}^{-2} \mathrm{se}^{-1}$ during the first spawning event and $0.01 \mathrm{~g}$

$300 \mathrm{~g}^{-1} \mathrm{~m}^{-2} \mathrm{se}^{-1}$ during the second one, while it was 0.11 and $0.08 \mathrm{~g} \mathrm{~g}^{-1} \mathrm{~m}^{-2} \mathrm{se}^{-1}$ for the CS class. Total

301 gamete output (TGO) and mean gamete output (MGO) of the US individuals, whose density was

$3020.4 \pm 0.1$ individuals per $\mathrm{m}^{2}$, were 0.03 and $0.01 \mathrm{~g} \mathrm{~g}^{-1} \mathrm{~m}^{-2} \mathrm{yr}^{-1}$ respectively. Meanwhile they were

3030.19 and $0.10 \mathrm{~g} \mathrm{~g}^{-1} \mathrm{~m}^{-2} \mathrm{yr}^{-1}$ for the CS class, whose natural density was $2.7 \pm 0.3$ individuals per

$304 \mathrm{~m}^{2}$. Consequently, the total gamete output of the whole population was estimated to be $0.22 \mathrm{~g} \mathrm{~g}^{-1}$

$305 \mathrm{~m}^{-2} \mathrm{yr}^{-1}$ and the total mean gamete output was $0.11 \mathrm{~g} \mathrm{~g}^{-1} \mathrm{~m}^{-2} \mathrm{yr}^{-1}$ (Table 2). 


\section{DISCUSSION}

308 The results showed a considerable difference between the two zones in population structure and

309 in abundance of sea urchins, as well as in the gonadosomatic index trend throughout the

310 surveyed year. As consequence, even the potential reproductive contribution differed between

311 the two populations.

312 While recruits (TD $<20 \mathrm{~mm}$ ) had the same proportion of population structure, the density of the

313 fertile undersized individuals (US) was 4.5-fold higher at the HP zone than at the LP one, and the

314 density of the commercial size (CS) was $\sim 7$-fold lower. Furthermore, within the commercial

315 size, a large percentage was composed of individuals $\geq 60 \mathrm{~mm}$ at the LP zone, while they were

316 nearly absent at the HP zone (none have been detected during the sampling for the estimation of

317 the population structure, only 24 throughout the annual sampling for the GSI assessment). Both

318 populations showed a spawning event at the end of winter or at the beginning of spring, which

319 lasted until April-May for the two fertile size classes examined (US and CS). Moreover, a second

320 relevant peak of GSI was registered in the LP zone which was demonstrated to be concomitant

321 with a spawning event from June 2013 (Siliani et al., 2016) by histological analysis. This is

322 consistent with observations from other areas of the Mediterranean where one or two annual

323 spawning periods were commonly identified, regardless of the proportion of size classes shaping

324 the population structure (Fenaux, 1968; Semroud \& Kada, 1987; Pedrotti \& Fenaux, 1992;

325 Pedrotti, 1993; Semroud, 1993; Lozano et al., 1995; Fernandez \& Boudouresque, 1997; López et

326 al., 1998; Guettaf, San Martin \& Francour, 2000; Leoni et al., 2003; Martínez et al., 2003; 
327 Sánchez-España, Martinez-Pita \& Garcia, 2004; Tomas, Romero \& Turon, 2004; Sellem \&

328 Guillou, 2007).

329 The differences identified in reproductive potential between the populations were not ascribed to 330 different environmental features since the sampling zones were similar in terms of sheltering

331 from waves and there were no differences found for either water temperature or algal

332 assemblages. Therefore, since fecundity depends on food availability and other environmental

333 characteristics (Minor \& Scheibling, 1997; Scheibling \& Hatcher, 2007), the two populations

334 could be considered similar in their ability to produce offspring.

335 At both zones, GSI of the Small US individuals was lower than $1 \%$ throughout the year,

336 therefore its contribution to the reproductive potential of the population was considered

337 negligible. On the contrary, GSI of the two fertile size classes (US and CS) changed significantly

338 over the year and between zones. Specifically, GSI of the CS class was significantly higher than

339 those of the US individuals and it was significantly higher in the LP zone than in the HP zone.

340 Growth rate is one of the main factors that may influence the size-frequency distribution of a sea

341 urchin population (Dix, 1972; Barry \& Tegner, 1990), and it can differ among populations (e.g.

342 Sellem, Langar \& Pesando, 2000; Turon et al., 1995). However, a previous study conducted in

343 the same zones by Loi et al. (2013) showed that the growth rates of the two populations were

344 comparable (Fig. S5). Definitively, as widely described in many other locations of the

345 Mediterranean (Guidetti, Terlizzi \& Boero, 2004; Gianguzza et al., 2006; Pais et al., 2007;

346 Ceccherelli, Pinna \& Sechi, 2009; Bertocci et al., 2014), our study clearly points out how human

347 predation adversely affects the population structure in the HP zone, truncating the adult cohorts

348 with $\mathrm{TD} \geq 50 \mathrm{~mm}$. The high presence of commercial-size adults (TD $\geq 50 \mathrm{~mm}$ ) at the LP zone, 
349 and in particular the high number of individuals larger than $60 \mathrm{~mm}$, confirmed this evidence.

350 Furthermore, these results are in agreement with previous studies on population structure

351 performed at Su Pallosu Bay (Guala et al., 2006) and Tavolara - Punta Coda Cavallo (Guala,

352 Simeone \& Baroli, 2009) (Fig. S6).

353 More interestingly, our results suggest the existence of a strong connection between the

354 contribution to the reproductive potential of the fertile size classes and the pressure of

355 commercial harvesting. Since the mean density of the US individuals at the HP zone was similar

356 to the mean density of the CS sea urchins at the LP zone, and vice versa, the mean gamete output

357 of the population (popMGO) was similar at the two zones but the contribution of the two fertile

358 size classes was specular. The US individuals were therefore the main producers of gametes at

359 the HP zone while the CS ones were likely annihilated by harvesting. On the other hand, at the

360 LP zone, the main producer was the CS class probably because the US individuals were strongly

361 reduced by fish predation as a response to protection measures (Sala, 1997; Hereu et al., 2005;

362 Parravicini et al., 2010).

363 In contrast, the total gamete output of the population (popTGO), which represented the annual

364 reproductive contribution of populations throughout the year, was two-fold higher at the LP

365 zone. Mita et al. (2007) suggested that gonad size increases volumetrically with sea urchin test

366 diameter, with the largest body size implying the most mature and developed gonads (and the

367 consequent possibility to produce more than one cohort of gametes). Effectively, in marine

368 reserves, more fertile gametes are produced by the largest sea urchins compared to sites where

369 large sea urchins are lacking (Lundquist, 2000). Moreover, the very important effects related to

370 the individual's age and size are proven by studies conducted on different fish species that have

371 demonstrated how a greater age diversity in a spawning stock may extend spawning both 
372 temporally and spatially. This, in consequence, increases the chances that more offspring

373 encounter favourable conditions for development (Secor, 2000; Berkeley et al., 2004b;

374 Fiorentino et al., 2008).

375 Despite the fact that a single year of study is not enough to unambiguously establish the

376 regularity of reproductive episodes throughout time, the number of spawning events we observed

377 at the two zones are consistent, respectively, with previous GSI studies conducted at Tavolara -

378 Punta Coda Cavallo (Guala, Simeone \& Baroli, 2009) and in a location in the Sinis peninsula,

379 contiguous to Su Pallosu Bay (Baroli et al., 2006), that is intensely affected by fishing (Marra et

380 al., 2016) (Fig. S7). Thus, since the popMGO strongly depended on the density per $\mathrm{m}^{2}$ of fertile

381 individuals regardless of their size class, it would be plausible that the continuous catch of

382 commercial-sized sea urchins has led to a reduction of spawning events due to a considerable

383 decrease of the body size of the fertile individuals. Hence, it might be reasonable to suppose that

384 spawning events were favoured by the well-structured spawning stock and larger sea urchins

385 which are typical of protected populations.

In general, sea urchin population dynamics is driven by various ecological processes that operate

on different spatial and temporal scales. Larval supply fluctuates widely from region to region as

it is associated with oceanic currents (Fenaux, Cellario \& Rassoulzadegan, 1988; Prado et al., 2012). The success of settlements is influenced by local constraints linked to habitat (e.g. adult abundance, presence of crustose algae, substrate rugosity) (Boudouresque \& Verlaque, 2007,

391 Oliva et al., 2016). Finally, predation becomes the prevalent mechanism of sea urchin population control after settlement and serves as a critical bottleneck for urchin populations (Guidetti, 2004; Hereu et al., 2005; Farina et al., 2009; Farina et al., 2014; Boada et al., 2015). In our case, the 
395 of harvesting are likely to shift the whole potential reproductive contribution onto the young

396 adults. On the contrary, in the LP zone, it mostly depended on commercial-sized individuals

397 since predation in marine reserves significantly affects sea urchins until they reach the size of 50

398 mm TD (Guidetti, 2004).

399 Therefore, we could state that the self-sustenance of the sea urchin populations did not change

400 between the two zones, despite the different harvesting pressure. The high number of recruits at

401 the HP zone ensured an availability of new juveniles for the immediate future and suggested an

402 important larval input of which the origin still has to be investigated. However, the two spawning

403 events at the LP zone suggested a more abundant and successful gamete production than in the

404 population which was under strong fishing pressure. This is probably due to a well-structured

405 spawning stock which enhanced the resilience of the pristine population. Hence, in equal

406 recruitment conditions, when the density of fertile individuals decreased (e.g. as a result of

407 intense commercial harvesting or natural predation) the mean reproductive contribution

408 consequently diminished.

409 Because of over-exploitation of P. lividus populations in several Mediterranean areas (Pais et al.,

410 2012; Bertocci et al., 2014) and their ecological (Sala et al., 1998) and economic relevance

411 (Palacín et al., 1998), sea urchin fisheries need urgent and effective regulation. Our findings may

412 have important implications for creating a management of sea urchin fisheries that is effective in

413 terms of the sustainable conservation of resources.

414 In a marine reserve context, where sea urchin populations have a normal bimodal structure

415 (Brundu et al., 2013), the opening of commercial harvesting should be avoided (despite the

416 insistence of local fishermen) to prevent the depletion of fertile individuals, as a result of the 
417 synergistic action with the natural predation, and the breakdown of the population. On the

418 contrary, in areas affected by fishing pressure, larger individuals are lacking (Baroli et al., 2006),

419 but the survival of the fertile, intermediate-size classes, which therefore support the mean gamete

420 output of the whole population, is guaranteed by laws (as harvesting is authorized only for

421 individuals $\geq 50 \mathrm{~mm}$ ) and by the absence of predatory fishes, which in turn are targeted by

422 commercial fishing.

423 Our present findings suggest that the reproductive potential contribution of the population does

424 not depend on the size of fertile individuals but on their density. For this reason, the harvesting

425 of individuals between 40 and $50 \mathrm{~mm}$ should be avoided particularly in over-fished locations,

426 since they are the only ones capable of generating new life, as far as we know without more

427 information on the origin of the larvae present.

\section{ACKNOWLEDGEMENTS}

430 We are grateful to the staff of Tavolara - Punta Coda Cavallo Marine Protected Area and to

B. Cristo for assistance and help in the field. M.A. Figus, A. Pinna, D. Vallainc, M.L.

Vitelletti are gratefully acknowledged for helping in lab activities. We would like to thank L.

433 Fazioli for providing us sea surface temperatures. Discussions with G. Ceccherelli and S.

434 Guerzoni, during the various stages of this study, were of great help and much appreciated.

435 Furthermore, the authors would like to acknowledge the contribution of the anonymous

436 reviewers who significantly helped to improve the original manuscript. 


\section{REFERENCES}

439 Anderson MJ. 2001a. A new method for non-parametric multivariate analysis of variance.

440 Austral Ecology 26: 32-46.

441 Anderson MJ. 2005. PERMANOVA: a FORTRAN computer program for permutational 442 multivariate analysis of variance. Department of Statistics, University of Auckland, New 443 Zealand.

444 Anderson SC, Mills Flemming J, Watson R, Lotze HK. 2011. Rapid Global Expansion of 445 Invertebrate Fisheries: Trends, Drivers, and Ecosystem Effects. PLoS ONE 6: e14735.

446 Andrew NL, Agatsuma Y, Ballesteros E, Bazhin AG, Creaser EP, Barnes DKA, Botsford LW, 447 Bradbury A, Campbell A, Dixon JD, Einarsson S, Gerring PK, Hebert K, Hunter M, Hur SB, 448 Johnson CR, Juinio-Menez MA, Kalvass P, Miller RJ, Moreno CA, Palleiro JS, Rivas D, 449 Robinson SML, Schroeter SC, Steneck RS, Vadas RL, Woodby DA, Xiaoqi Z. 2002. Status and 450 management of world sea urchin fisheries. Oceanography And Marine Biology An Annual 451 Review 40: 343-425.

452 Baroli M, De Falco G, Sanna O, Paliaga B. 2006. Monitoraggio della popolazione del riccio di 453 mare Paracentrotus lividus nell'Area Marina Protetta Penisola del Sinis - Isola di Mal di Ventre. 454 Technical report Fondazione IMC, 35 pp.

455 Barry JP, Tegner MJ. 1990. Inferring demographic process from size-frequency distributions: 456 simple models indicate specific patterns of growth and mortality. Fishery Bulletin 88: 13-19.

457 Bell JE, Bishop MJ, Taylor RB, Williamson JE. 2014. Facilitation cascade maintains a kelp 458 community. Marine Ecology Progress Series 501: 1-10. 
459 Berkeley SA, Hixon MA, Larson RJ, Love MS. 2004b. Fisheries sustainability via protection of 460 age structure and spatial distribution of fish populations. Fisheries 29: 23-32.

461 Bertocci I, Dominguez R, Machado I, Freitas C, Domínguez Godino J, Sousa-Pinto I, Gonçalves

462 M, Gaspar MB. 2014. Multiple effects of harvesting on populations of the purple sea urchin

463 Paracentrotus lividus in north Portugal. Fisheries Research 150: 60-65.

464 Boada J, Rohan A, Farina S, Santana Y, Mascaró O, Romero J, Alcoverro T. 2015. Hotspots of 465 predation persist outside marine reserves in the historically fished Mediterranean Sea. Biological 466 Conservation 191: 67-74.

467 Boudouresque CF, Verlaque M. 2007. Ecology of Paracentrotus lividus. In: Lawrence JM, ed. 468 Edible sea urchins: biology and ecology. Amsterdam: Elsevier, 243-285.

469 Brady SM, Scheibling RE. 2006. Changes in growth and reproduction of green sea urchins, 470 Strongylocentrotus droebachiensis (Müller), during repopulation of the shallow subtidal zone 471 after mass mortality. Journal of Experimental Marine Biology and Ecology 335: 277-291.

472 Brewin PE, Lamare MD, Keogh JA, Mladenov PV. 2000. Reproductive variability over a four473 year period in the sea urchin Evechinus chloroticus (Echinoidea: Echinodermata) from differing 474 habitats in New Zealand. Marine Biology 137: 543-557.

475 Brundu G, Loi B, Baroli M, Frau F, Panzalis P, Bernardi G, Navone A, Guala I. 2013. Change of 476 density and structure of sea urchin population at the MPA Tavolara - Punta Coda Cavallo).

477 Biologia Marina Mediterranea 20: 122-123.

478 Brundu G, Vallainc D, Baroli M, Figus MA, Pinna A, Carboni S. 2016. Effects of on-demand 479 feeding on sea urchin larvae (Paracentrotus lividus; Lamarck, 1816), development, survival and 
480 microalgae utilization. Aquaculture Research: 1-11.

481 Byrne M. 1990. Annual reproductive cycles of the commercial sea urchin Paracentrotus lividus 482 from an exposed intertidal and a sheltered subtidal habitat on the west coast of Ireland. Marine 483 Biology 104: 275-289.

484 Ceccherelli G, Pinna S, Sechi N. 2009. Evaluating the effects of protection on Paracentrotus 485 lividus distribution in two contrasting habitats. Estuarine, Coastal and Shelf Science 81: 59-64.

486 Coll M, Lotze HK, Romanuk TN. 2008a. Structural Degradation in Mediterranean Sea Food 487 Webs: Testing Ecological Hypothesis Using Stochastic and Mass-Balance Modeling. Ecosystems $488 \quad 11: 939-960$.

Coll M, Palomera I, Tudela S. 2009a. Decadal Changes in a NW Mediterranean Sea Food Web 490 in Relation to Fishing Exploitation. Ecological Modelling 220: 2088-2102. Last Three Decades. Marine Ecology Progress Series 381: 17-37.

Di Franco A, Bussotti S, Navone A, Panzalis P, Guidetti P. 2009. Evaluating effects of total and 494 partial restrictions to fishing on Mediterranean rocky-reef fish assemblages. Marine Ecology 495 Progress Series 387: 275-285.

Dix TG. 1972. Biology of Evechinus chloroticus (Echinoidia: Echinometridae) from different 497 localities. New Zealand Journal of Marine and Freshwater Research 6: 46-48.

498 Estes JA, Duggins DO, Rathbun GB. 1989. The ecology of extinctions in kelp forest 499 communities. Conservation Biology 3: 252-264. 
500 Falugi C, Angelini C. 2002. Sea urchin development from the egg to metamorphosis: an

501 integrated model for cell-to-cell and environment interaction. In: Yokota Y, Matranga V,

502 Smolenicka Z, eds. The sea urchin: from basic biology to aquaculture. Lisse: AA Balkema, $73-$

50393.

504 Farina S, Tomas F, Prado P, Romero J, Alcoverro T. 2009. Seagrass meadow structure alters

505 interactions between the sea urchin Paracentrotus lividus and its predators. Marine Ecology

506 Progress Series 377: 131-137.

507 Farina S, Arthur R, Pagès JF, Prado P, Romero J, Vergés A, Hyndes G, Heck KL, Glenos S,

508 Alcoverro, T. 2014. Differences in predator composition alter the direction of structure-mediated

509 predation risk in macrophyte communities. Oikos 123: 1311-1322.

510 Fenaux L. 1968. Maturation des gonades et cycle saisonnier des larves chez A. lixula, P.lividus et

511 P.microtuberculatus à Villefranche-Sur-Mer. Vie Milieu Serie A 19: 1-52.

512 Fenaux L, Cellario C, Rassoulzadegan F. 1988. Sensitivity of different morphological stages of

513 the larva of Paracentrotus lividus (Lamarck) to quantity and quality of food. In: Burke D,

514 Mladenov PV, Lambert P, Parsley RL, eds. Echinoderm biology. Rotterdam: A.A. Balkema,

$515259-266$.

516 Fernandez C, Boudouresque CF. 1997. Phenotypic plasticity of Paracentrotus lividus

517 (Echinodermata: Echinoidea) in a lagoonal environment. Marine Ecology Progress Series 152:

$518 \quad 145-154$.

519 Fiorentino F, Badalamenti F, Anna GD, Garofalo G, Gianguzza P, Gristina M, Pipitone C, Rizzo

520 P, Fortibuoni T, Anna D, Changes T. 2008. Changes in spawning-stock structure and recruitment 
521 pattern of red mullet, Mullus barbatus, after a trawl ban in the Gulf of Castellammare (central

522 Mediterranean Sea). ICES Journal of Marine Science 65: 1175-1183.

523 Gianguzza P, Chiantore M, Bonaviri C, Cattaneo-Vietti R, Vielmini I, Riggio S. 2006. The

524 effects of recreational Paracentrotus lividus fishing on distribution patterns of sea urchins at

525 Ustica Island MPA (Western Mediterranean, Italy). Fisheries Research 81: 37-44.

526 Gianguzza P, Bonaviri C, Prato E, Fanelli G, Chiantore M, Privitera D, Luzzu F, Agnetta D.

527 2013. Hydrodynamism and its influence on the reproductive condition of the edible sea urchin

528 Paracentrotus lividus. Marine Environmental Research 85: 29-33.

529 Guala I, De Lucia GA, De Falco G, Domenici P, Paliaga B. 2006. Monitoraggio dell’effetto 530 riserva nell'Area Marina Protetta Penisola del Sinis - Isola di Mal di Ventre. Technical report 531 Fondazione IMC, $35 \mathrm{pp}$.

532 Guala I, Simeone S, Baroli M. 2009. Abbondanza e struttura della popolazione di Paracentrotus 533 lividus nell'Area Marina Protetta Tavolara - Punta Coda Cavallo. Technical report Fondazione $534 \mathrm{IMC}, 34 \mathrm{pp}$.

535 Guala I, Simeone S, Navone A, Panzalis P, Baroli M. 2011. Valutazione della sostenibilità del 536 prelievo del riccio di mare Paracentrotus lividus nell'Area Marina Protetta Tavolara - Punta 537 Coda Cavallo. Studi Trentini di Scienze Naturali 89: 119-121.

538 Guettaf M, San Martin GA, Francour P. 2000. Interpopulation variability of the reproductive 539 cycle of Paracentrotus lividus (Echinodermata: Echinoidea) in the south-western Mediterranean. 540 Journal of the Marine Biological Association of the UK 80: 899-907.

541 Guidetti P. 2004. Consumers of sea urchins, Paracentrotus lividus and Arbacia lixula, in shallow 
542 Mediterranean rocky reefs. Helgoland Marine Research 58: 110-116.

543 Guidetti P, Terlizzi A, Boero F. 2004. Effects of the edible sea urchin, Paracentrotus lividus,

544 fishery along the Apulian rocky coast (SE Italy, Mediterranean Sea). Fisheries Research 66:

$545 \quad 287-297$.

546 Hereu B, Zabala M, Linares C, Sala E. 2005. The effects of predator abundance and habitat

547 structural complexity on survival of juvenile sea urchins. Marine Biology 146: 293-299.

548 Jackson JBC, Kirby MX, Berger WH, Bjorndal KA, Botsford LW, Bourque BJ, Bradbury RH,

549 Cooke R, Erlandson J, Estes JA, Hughes TP, Kidwell S, Lange CB, Lenihan HS, Pondolfi JM,

550 Peterson CH, Steneck RS, Tegner MJ, Warner RR. 2001. Historical overfishing and the recent

551 collapse of coastal ecosystems. Science 293: 629-638.

552 Lawrence JM, Lawrence AL, Holland ND. 1965. Annual cycle in the size of the gut of the purple 553 sea urchin, Strongylocentrotus purpuratus (Stimpson). Nature 205:1238-1239.

554 Leoni V, Fernandez C, Johnson M, Ferrat L, Pergent-Martini C. 2003. Preliminary study on 555 spawning periods in the sea urchin Paracentrotus lividus from lagoon and marine environments.

556 In: Féral JP, David B, eds. Echinoderm research 2001. Lisse: AA Balkema, 277-280.

557 Levitan DR, Sewell MA. 1998. Fertilization success in free-spawning marine invertebrates:

558 review of the evidence and fisheries implications. In: G.S. Jamieson and Campbell A., eds.

559 Canadian Special Publication of Fisheries and Aquatic Sciences 125: 159-164.

560 Loi B, Brundu G, Guala I, Frau F, Panzalis P, Bernardi G, Navone A, Baroli M. 2013. Age and

561 growth of the sea urchin Paracentrotus lividus in Tavolara - Punta Coda Cavallo Marine

562 Protected Area (Sardinia). Biologia Marina Mediterranea 20: 138-139. 
563 López S, Turon X, Montero E, Palacín C, Duarte CM, Tarjuelo I. 1998. Larval abundance,

564 recruitment and early mortality in Paracentrotus lividus (Echinoidea). Interannual variability and

565 plankton-benthos coupling. Marine Ecology Progress Series 172: 239-251.

566 Lotze HK, Coll M, Dunne JA. 2011. Historical Changes in Marine Resources, Food Web

567 Structure and Ecosystem Functioning in the Adriatic Sea, Mediterranean. Ecosystems 14: 198568222.

569 Lozano J, Galera J, Lopez S, Turon X, Palacin C, Morera G. 1995. Biological cycles and

570 recruitment of Paracentrotus lividus (Echinodermata: Echinoidea) in two contrasting habitats.

571 Marine Ecology Progress Series 122: 179-192.

572 Lundquist CJ. 2000. Effects of density dependence and environment on recruitment of coastal 573 invertebrates. D. Phil. Thesis, University of California.

574 Marra S, Coppa S, Camedda A, Mazzoldi C, Wrachien F, Massaro G, De Lucia GA. 2016.

575 Recovery trends of commercial fish: The case of an underperforming mediterranean marine 576 protected area. PLOS ONE 11: 1-22.

577 Martínez I, García FJ, Sánchez AI, Daza JL, Del Castillo F. 2003. Biometric parameters and

578 reproductive cycle of Paracentrotus lividus (Lamarck) in three habitats of Southern Spain. In:

579 Féral JP, David B, eds. Echinoderm Research 2001. Lisse: AA Balkema, 281-287.

580 Meidel SK, Scheibling RE. 1998. Annual reproductive cycle of the green sea urchin,

581 Strongylocentrotus droebachiensis, in differing habitats in Nova Scotia, Canada. Marine Biology

582 131: 461-478.

583 Minor MA, Scheibling RE. 1997. Effects of food ration and feeding regime on growth and 
584 reproduction of the sea urchin Strongylocentrotus droebachiensis. Marine Biology 129: 159-167.

585 Mita M, Sato J, Hirosawa Y, Nakamura M. 2007. Gonadal maturation is dependent on body size

586 in the sea urchin, Echinometra tsumajiroi. Invertebrate Reproduction \& Development 50: 187-

587190.

588 Myers RA, Worm B. 2003. Rapid worldwide depletion of predatory fish communities. Nature

589 423: 280-283.

590 Navia AF, Cortés E, Jordán F, Cruz-Escalona VH, Mejía-Falla PA. 2012. Changes to marine

591 trophic networks caused by fishing. In: Mahamane A, ed. Diversity of Ecosystems. Croatia:

592 InTech Press, 418-452.

593 Oliva S, Farina S, Pinna S, Guala I, Agnetta D, Ariotti PA, Mura F, Ceccherelli G. 2016.

594 Determinants of Paracentrotus lividus sea urchin recruitment under oligotrophic conditions:

595 implications for conservation management. Marine Environmental Research 117: 13-20.

596 Ouréns R, Fernández L, Freire J. 2011. Geographic, population, and seasonal patterns in the

597 reproductive parameters of the sea urchin Paracentrotus lividus. Marine Biology 158: 793-804.

598 Pais A, Chessa LA, Serra S, Ruiu A, Meloni G, Donno Y. 2007. The impact of commercial and

599 recreational harvesting for Paracentrotus lividus on shallow rocky reef sea urchin communities

600 in North-western Sardinia, Italy. Estuarine, Coastal and Shelf Science 73: 589-597.

601 Pais A, Serra S, Meloni G, Saba S, Ceccherelli G. 2012.Harvesting effects on Paracentrotus

602 lividus population structure: A case study from northwestern Sardinia, Italy, before and after the

603 fishing season. Journal of Coastal Research 28: 570-575.

604 Palacín G, Giribet G, Carner S, Dantart L, Turon X. 1998. Low densities of sea urchins influence 
605 the structure of algal assemblages in the western Mediterranean. Journal of Sea Research 39:

$606 \quad 281-290$.

607 Parravicini V, Guidetti P, Morri C, Montefalcone M, Donato M, Bianchi CN. 2010.

608 Consequences of sea water temperature anomalies on a Mediterranean submarine cave

609 ecosystem. Estuarine, Coastal and Shelf Science 86: 276-282.

610 Pauly D. 1995. Anecdotes and the shifting baseline syndrome of fisheries. Trends in Ecology \&

611 Evolution 10: 430.

612 Pedrotti ML, Fenaux L. 1992. Dispersal of echinoderm larvae in a geographical area marked by 613 upwelling (Ligurian Sea, NW Mediterranean). Marine Ecology Progress Series 86: 217-227.

614 Pedrotti ML. 1993. Spatial and temporal distribution and recruitment of echinoderm larvae in the 615 Ligurian Sea. Journal of the Marine Biological Association UK 73: 513-530.

616 Pinnegar JK, Polunin NVC, Francour P, Badalament F, Chemello R, Harmelin-Vivien ML, 617 Hereu B, Milazzo M, Zabala M, D’Anna G, Pipitone C. 2000. Trophic cascades in benthic 618 marine ecosystems: lessons for fisheries and protected-area management. Environmental 619 Conservation 27: 179-200.

620 Prado P, Tomas F, Pinna S, Farina S, Roca G, Ceccherelli G, Romero J, Alcoverro T. 2012.

621 Habitat and Scale Shape the Demographic Fate of the Keystone Sea Urchin Paracentrotus 622 lividus in Mediterranean Macrophyte Communities. PLoS ONE 7: e35170.

623 RAS. 2013. Calendario della pesca del riccio di mare (Paracentrotus lividus) per la stagione 624 2013/2014. Regione Autonoma della Sardegna - Assessorato Agricoltura e Riforma Agro625 Pastorale. Decreto n. 1967/DecA/67 del 29.10.2013. 
626 Sala E, Zabala M. 1996. Fish predation and the structure of the sea urchin Paracentrotus lividus 627 populations in the NW Mediterranean. Marine Ecology Progress Series 140: 71-81.

628 Sala E. 1997. Fish predators and scavengers of the sea urchin Paracentrotus lividus in protected 629 areas of the north-west Mediterranean Sea. Marine Biology 129: 531-539.

630 Sala E, Boudouresque CF and Harmelin-Vivien M. 1998. Fishing, trophic cascades, and the 631 structure of algal assemblages: evaluation of an old but untested paradigm. Oikos 82: 425-439.

632 Sala E, Ribes M, Hereu B, Zabala M, Alvà V, Coma R, Garrabou J. 1998. Temporal variability 633 in abundance of the sea urchins Paracentrotus lividus and Arbacia lixula in the northwestern 634 Mediterranean: Comparison between a marine reserve and an unprotected area. Marine Ecology 635 Progress Series 168: 135-145.

636 Sánchez-España AI, Martínez-Pita I, García FJ. 2004. Gonadal growth and reproduction in the 637 commercial sea urchin Paracentrotus lividus (Lamarck, 1816) (Echinodermata: Echinoidea) 638 from southern Spain. Hydrobiologia 519: 61-72.

639 Scheibling RE, Hatcher BG. 2007. Ecology of Strongylocentrotus droebachiensis. In: Lawrence 640 JM, ed. Edible sea urchins: biology and ecology. Amsterdam: Elsevier, 353-392.

641 Secor DH. 2000. Spawning in the nick of time? Effect of adult demographics on spawning 642 behaviour and recruitment in Chesapeake Bay striped bass. ICES Journal of Marine Science 57: $643 \quad 403-411$.

644 Sellem F, Langar H, Pesando D. 2000. Âge et croissance de l'oursin Paracentrotus lividus 645 Lamarck, 1816 (Echinodermata: Echinoidea) dans le Golfe de Tunis (Méditerranée). 646 Oceanologica Acta 23, 607-613. 
647 Sellem F, Guillou M. 2007. Reproductive biology of Paracentrotus lividus (Echinodermata:

648 Echinoidea) in two contrasting habitats of northern Tunisia (south-east Mediterranean). Journal 649 of the Marine Biological Association of the UK 87: 763-767.

650 Semroud R, Kada H. 1987. Contribution a l'etude de l'oursin Paracentrotus lividus dans la 651 region d'Alger: indice de repletion et indice gonadique. In: Boudouresque CF, ed. Colloque 652 international sur Paracentrotus lividus et les oursins comestibles. Marseilles: GIS Posidonie, $653 \quad 117-124$.

654 Semroud R. 1993. Contribution à la connaissance de l'écosystème à Posidonia oceanica (L.) 655 Delile dans la région d'Alger (Algérie): etude de quelues compartiments. D. Phil. Thesis, 656 Université des Sciences et de la Technologie Houari Boumediene, Algeria.

657 Shpigel M, McBride SC, Marciano S, Lupatsch I. 2004. The effect of photoperiod and 658 temperature on the reproduction of the European sea urchin Paracentrotus lividus. Aquaculture 659 232: 343-355.

660 Siliani S, Melis R, Loi B, Guala I, Baroli M, Sanna R, Uzzau S, Roggio T, Filippa M, Anedda R. 661 2016. Influence of seasonal and environmental patterns on the lipid content and fatty acid 662 profiles in gonads of the edible sea urchin Paracentrotus lividus from Sardinia. Marine 663 Environmental Research 113: 124-133.

664 Spirlet C, Grosjean P, Jangoux M. 1998. Reproductive cycle of the echinoid Paracentrotus 665 lividus: analysis by means of the maturity index. Invertebrate Reproduction \& Development 34: $666 \quad 69-81$. 
667 Steneck RS, Graham MH, Bourque BJ, Corbett D, Erlandson JM, Estes JA, Tegner MJ. 2002.

668 Kelp Forest Ecosystem: Biodiversity, Stability, Resilience and their Future. Environmental 669 Conservation 29: 436-459.

670 Steneck RS, Vavrinec J, Leland AV. 2004. Accelerating Trophic Level Dysfunction in Kelp

671 Forest Ecosystems of the Western North Atlantic. Ecosystems 7: 323-332.

672 Teixidó N, Albajes-Eizagirre A, Bolbo D, Le Hir E, Demestre M, Garrabou J, Guigues L, Gili

673 JM, Piera J, Prelot T, Soria-Frisch A. 2011. Hierarchical Segmentation based software for Cover 674 Classification Analyses of Seabed Images (Seascape). Marine Ecology Progress Series 431: 4567553.

676 Tomas F, Romero J, Turon X. 2004. Settlement and recruitment of the sea urchin Paracentrotus 677 lividus in two contrasting habitats in the Mediterranean. Marine Ecology Progress Series 282: $678 \quad 173-184$.

679 Tortonese E. 1965. Echinodermata (Vol. VI). Fauna d'Italia. Bologna: Calderini.

680 Trippel EA. 1995. Age at maturity as a stress indicator in fisheries. BioScience, 45: 759-771.

681 Tunca S, Ünal V, Miran B, Güçlüsoy H, Gordoa A. 2016. Biosocioeconomic analysis of marine 682 recreational fisheries: A comparative case study from the Eastern Mediterranean, Turkey. 683 Fisheries Research 174: 270-279.

684 Turon X, Giribet G, López S, Palacín C. 1995. Growth and population structure of Paracentrotus 685 lividus (Echinodermata: Echinoidea) in two contrasting habitats. Marine Ecology Progress 686 Series 122, 193-204. 
687 Underwood AJ. 1997. Experiments in Ecology. Their logic design and interpretation using 688 analysis of variance. Cambridge: Cambridge University Press. 
Figure 1

Map of the study zones

Su Pallosu Bay, in the Sinis Peninsula, is considered a high-pressure zone (HP zone); Tavolara

- Punta Coda Cavallo is considered a low pressure zone (LP zone). Sampling areas, named A and B for Su Pallosu Bay, C and D for Tavolara - Punta Coda Cavallo, are represented by the black dots.

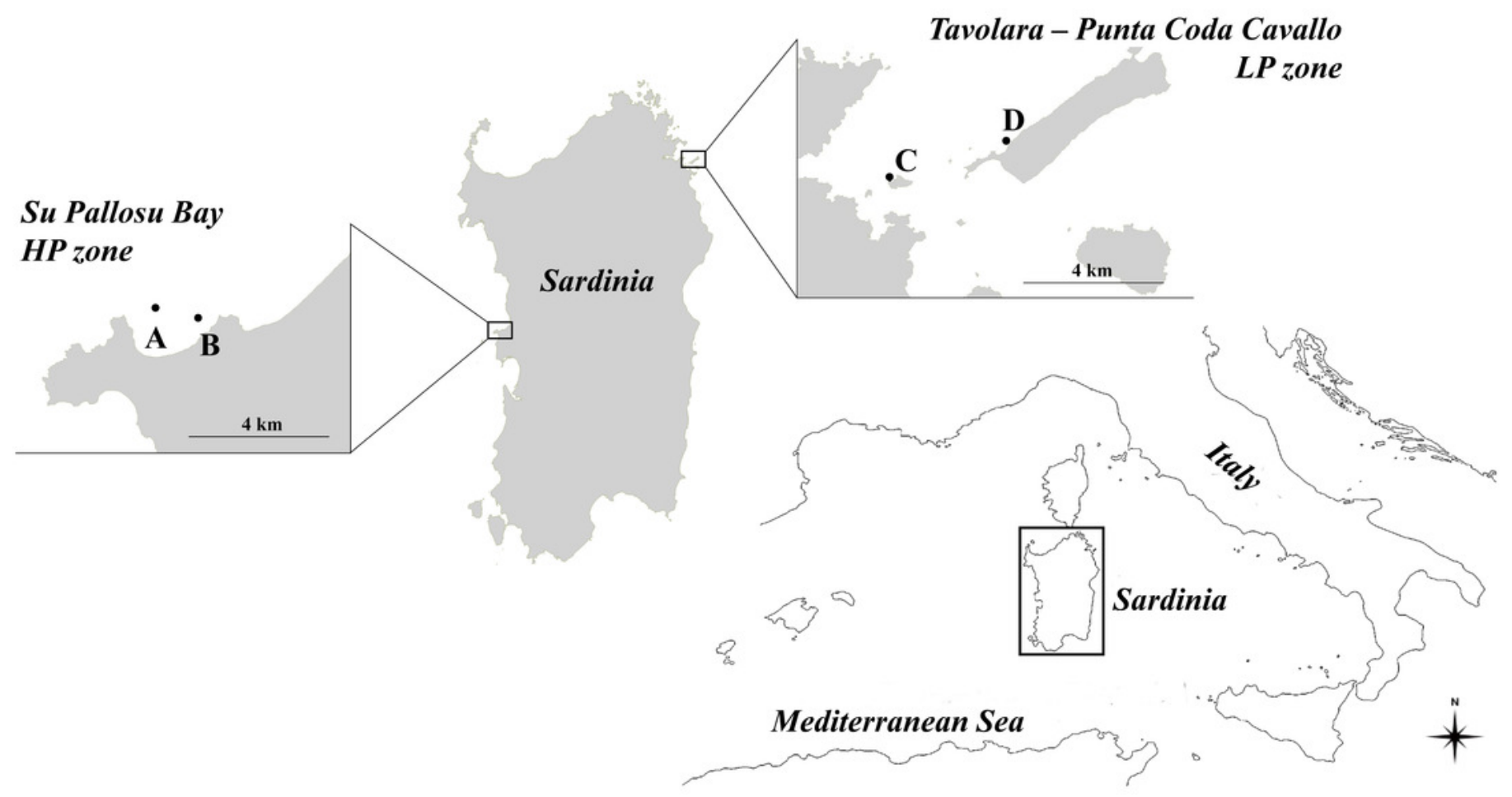




\section{Figure 2}

Annual trend of gonadosomatic index at sampling zones

GSI is represented as mean \pm standard error for the three size classes examined (CS, US, Small-US) at a) high-pressure zone (Su Pallosu Bay) and b) low-pressure zone (Tavolara Punta Coda Cavallo). No distinction between sexes was done in the graph, since females and males belonging to the same size class were pooled together. Observation began in June 2013 and ended in May 2014. However, November 2013 was not sampled due to general bad weather conditions and GSI data of CS and US classes were estimated from different years (i.e. November 2007 for Tavolara - Punta Coda Cavallo and November 2015/16 for Su Pallosu Bay). GSI data for Small-US class was not available for this month; the dotted line for the Small-US class represents an approximation of the expected values of GSI for November. Triangles $=$ CS; rhombuses $=$ US; squares $=$ Small-US. 
a

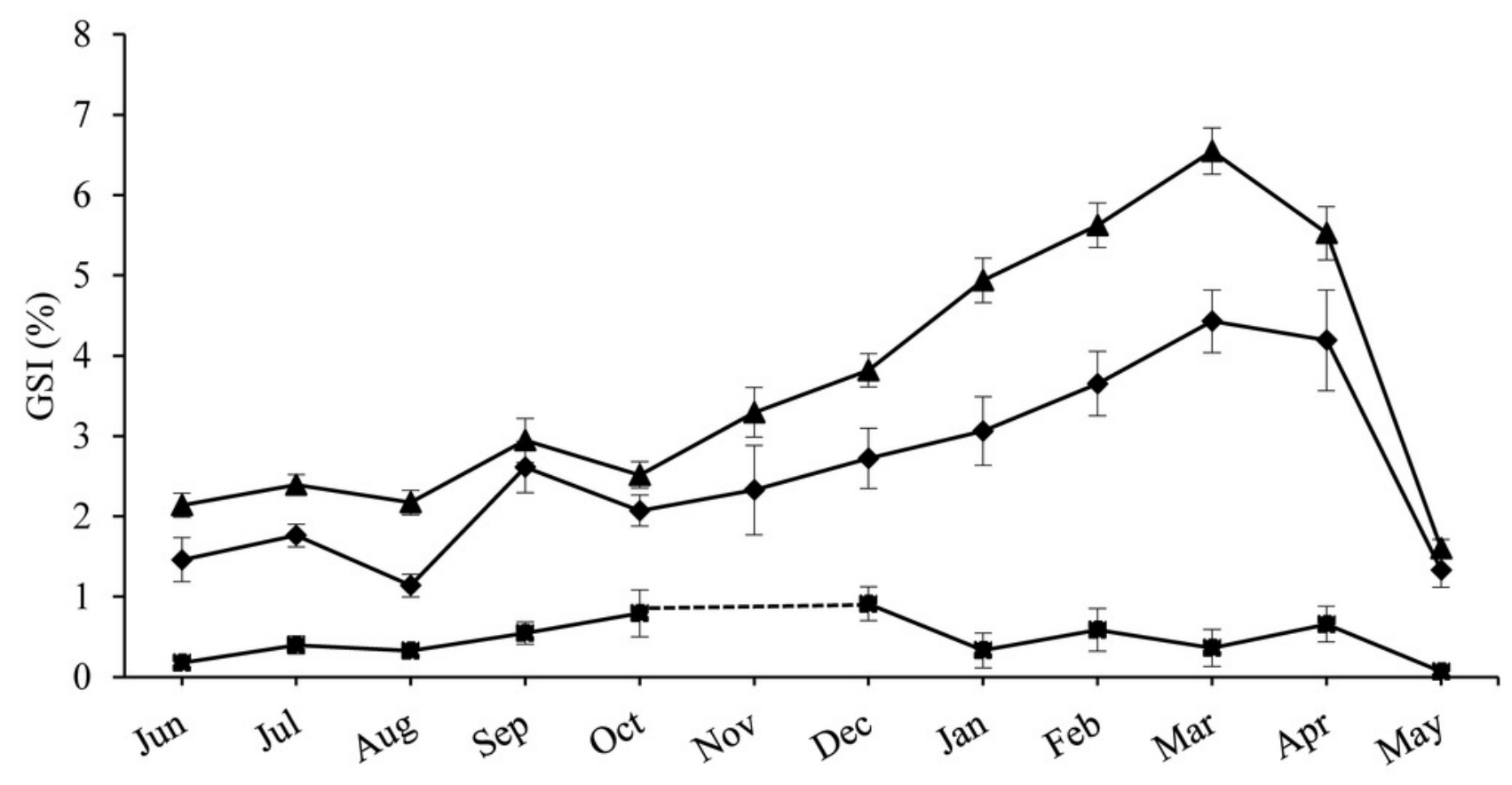

b

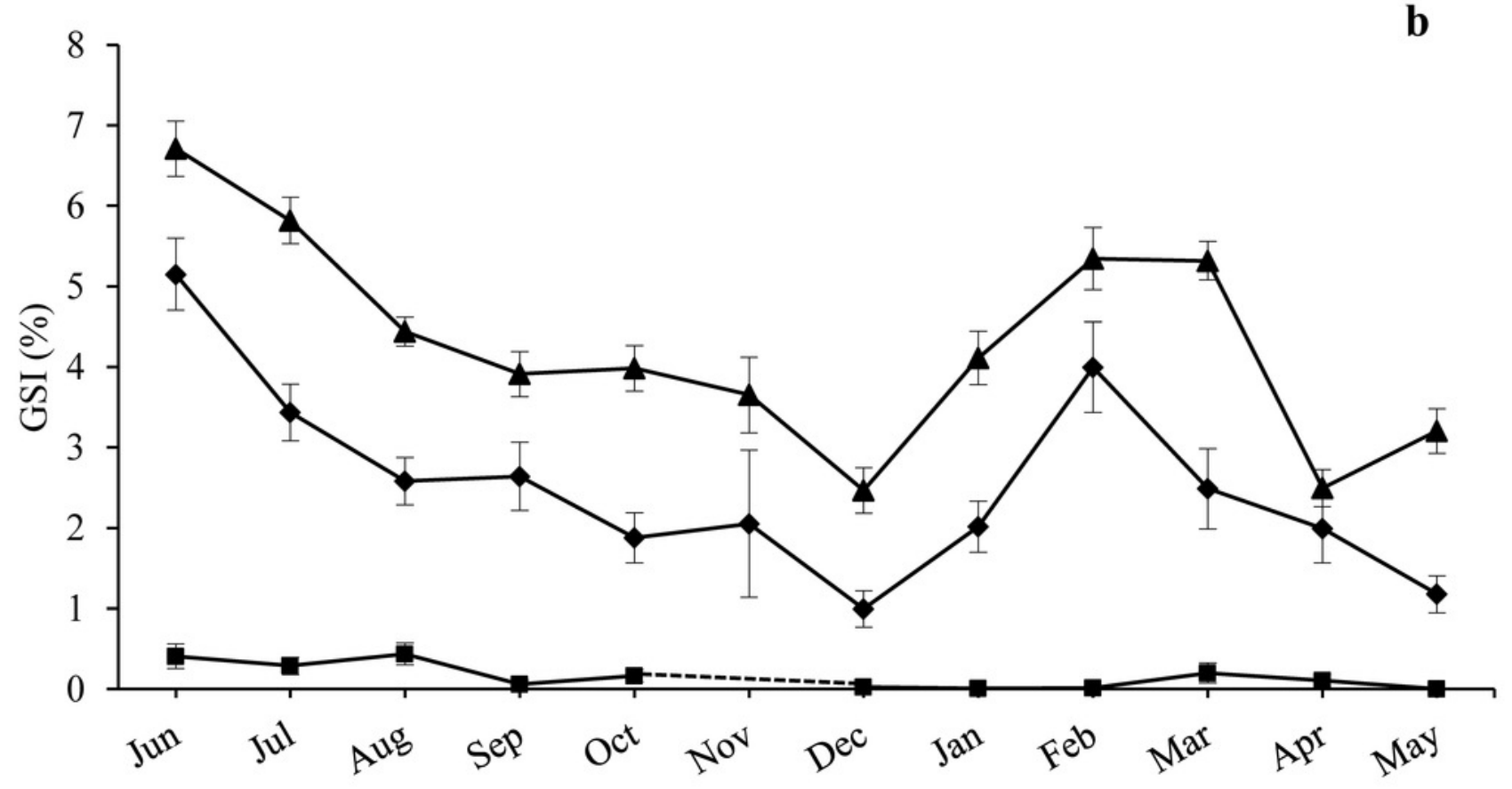




\section{Figure 3}

Size-frequency distribution (\%) of sea urchin populations at sampling zones

The range of the size classes is $10 \mathrm{~mm}$ of test diameter without spines (TD). Commercial size classes under fishing pressure are those larger than $50 \mathrm{~mm}$ test diameter. White bars = highpressure zone (Su Pallosu Bay); black bars = low-pressure zone (Tavolara - Punta Coda Cavallo).

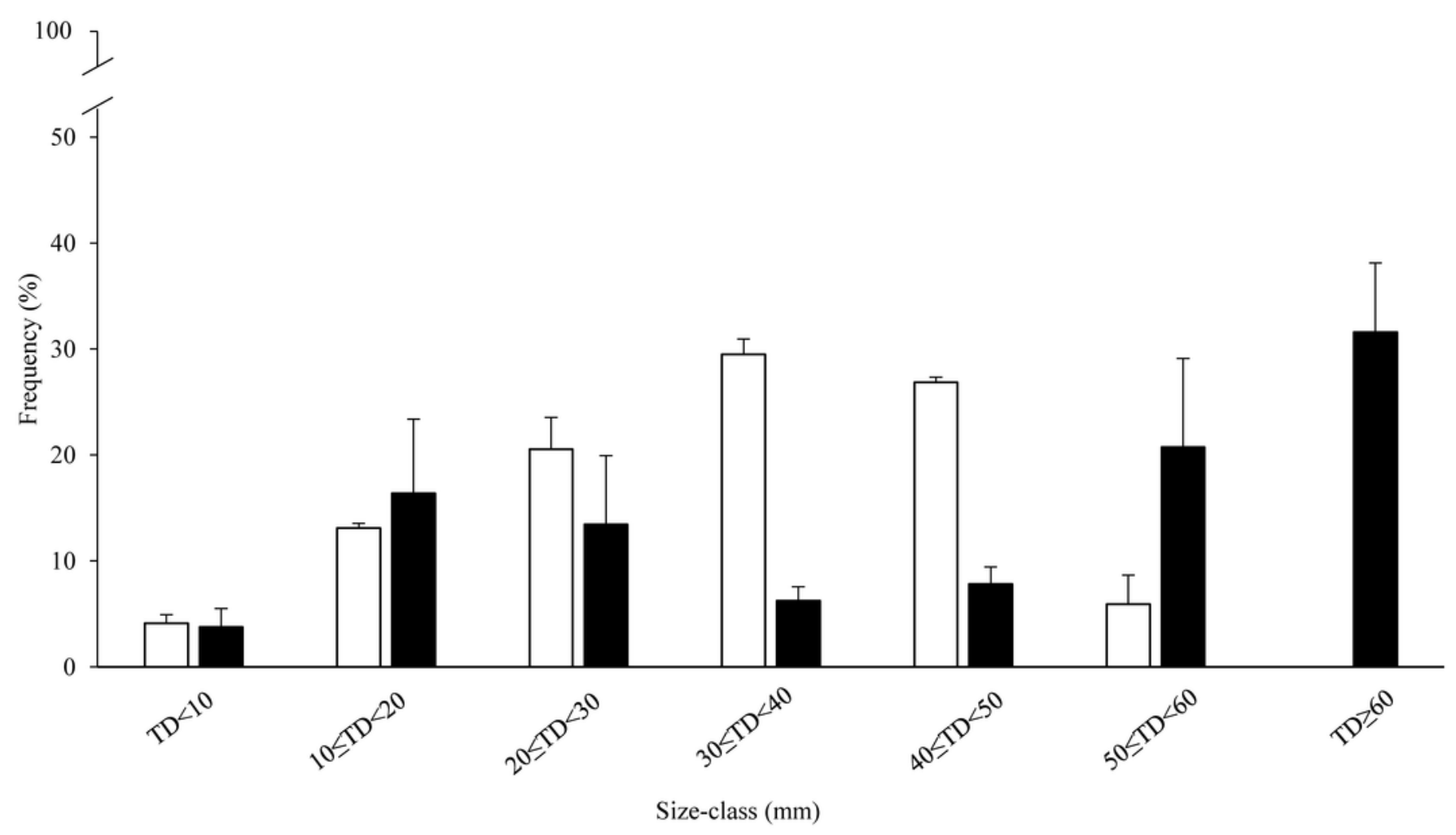




\section{Table $\mathbf{1}$ (on next page)}

\section{Results of four-way ANOVA}

Analysis of variance was performed to test the effects on gonadosomatic index of Month, Zone and Size class (orthogonal fixed factors) and Area (random nested factor in Zone). Bold value is statistically significant at $p<0.05$. SNK tests were conducted for comparisons of significant interactions. 


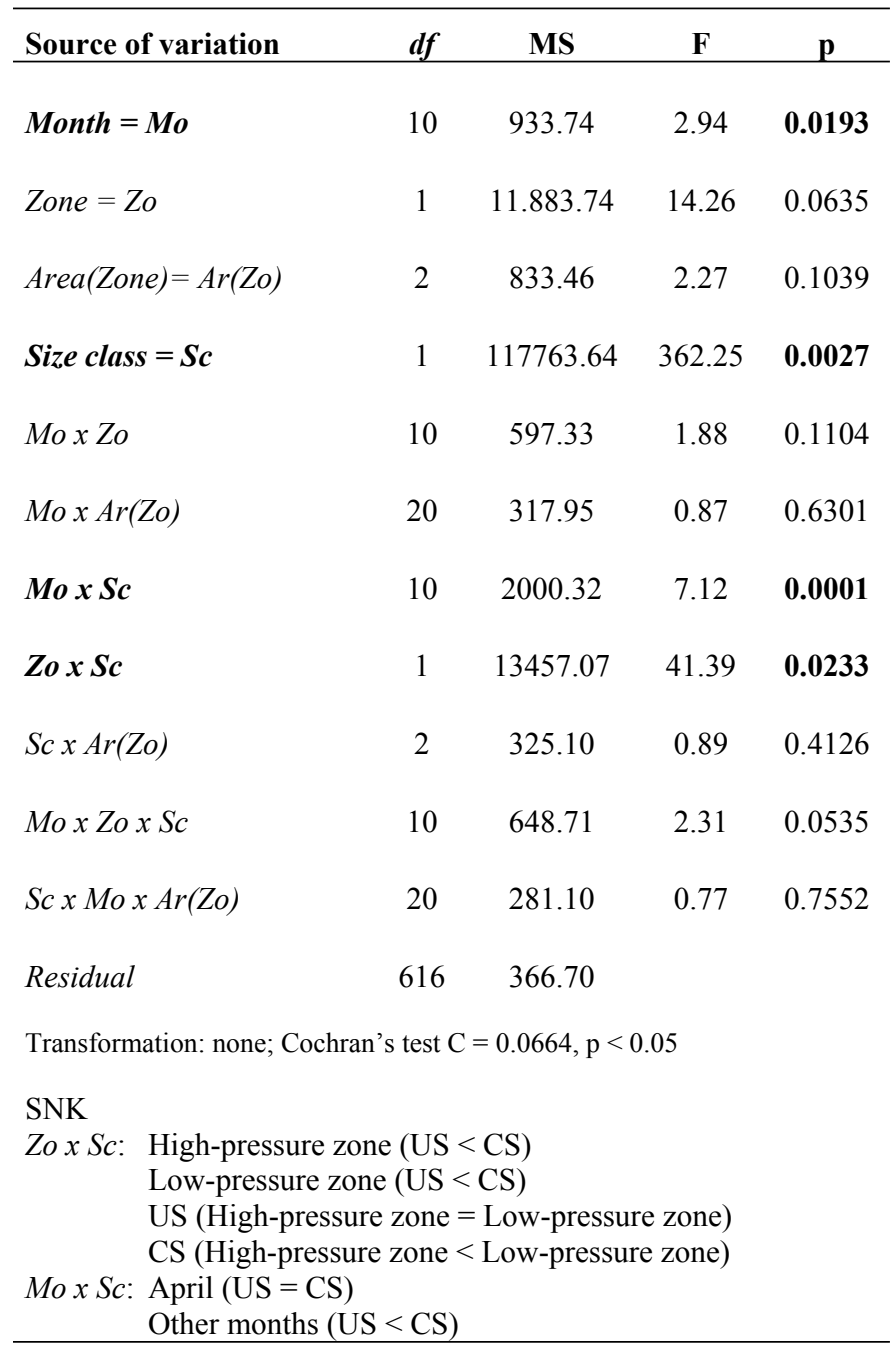




\section{Table 2 (on next page)}

Summary table of potential reproductive contribution results

Timing and extent of mean monthly gonadosomatic index, spawning magnitude, and gamete output for US ( $40 \leq$ TD $<50 \mathrm{~mm}$ ) and CS (TD $\geq 50 \mathrm{~mm}$ ) class, for spawning event and in relation with their natural density, and for the whole populations at high-pressure (Su Pallosu Bay) and low-pressure (Tavolara - Punta Coda Cavallo) zone. 


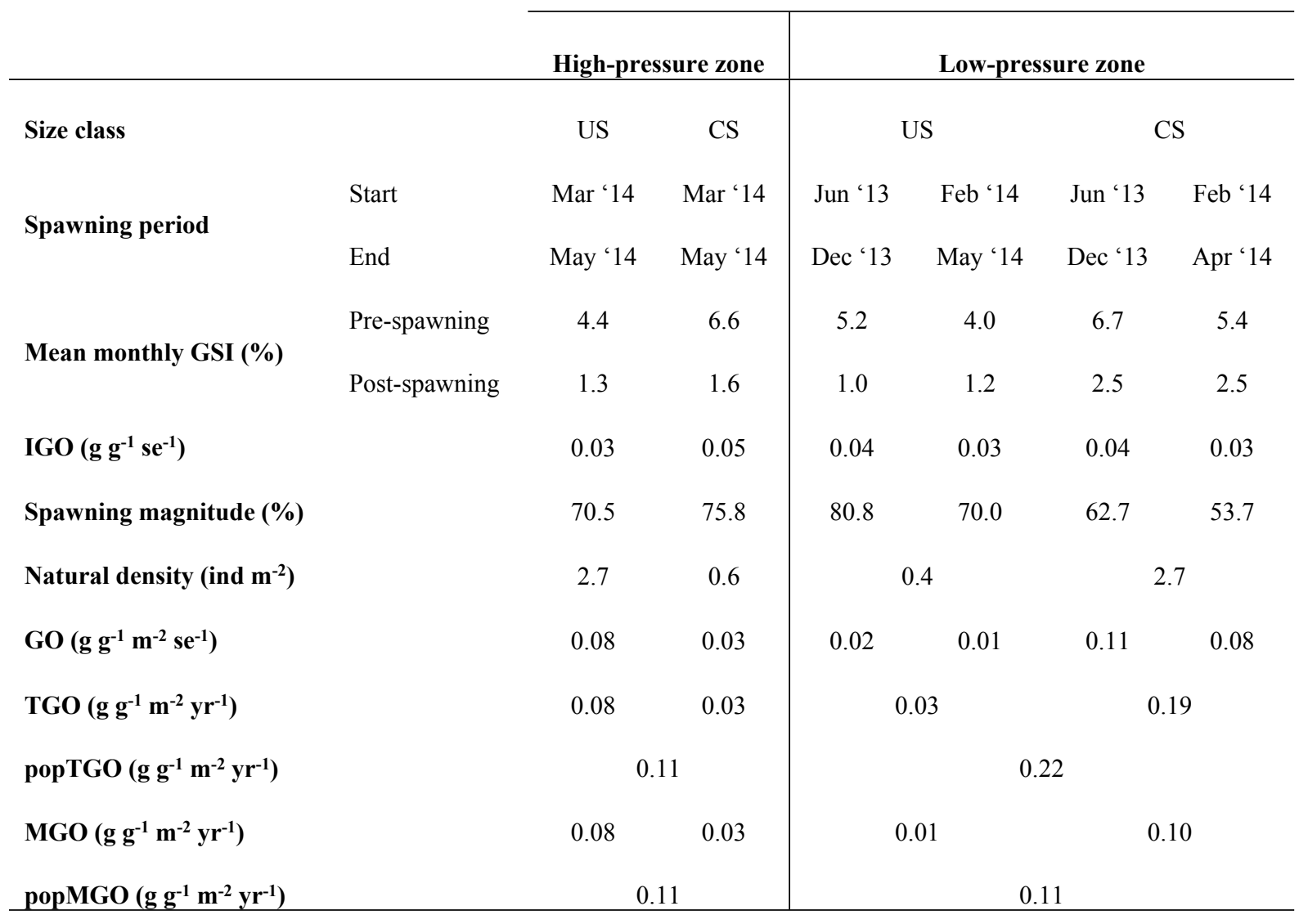

1

2

$3 \mathrm{IGO}=$ Individual Gamete Output per spawning event; $\mathrm{GO}=$ Gamete Output per $\mathrm{m}^{2}$; $\mathrm{TGO}=$ Total Gamete

4 Output per $\mathrm{m}^{2}$; popTGO $=$ Total Gamete Output of the whole population per $\mathrm{m}^{2}$; $\mathrm{MGO}=$ Mean Gamete

5 Output per $\mathrm{m}^{2}$; popMGO = Mean Gamete Output of the whole population per $\mathrm{m}^{2}$. 